\title{
Service Quality on Customer Satisfaction in Nepalese Commercial Banks
}

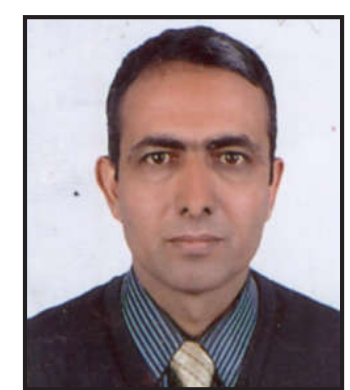

Pitambar Lamichhane, MPhil*

\begin{abstract}
This paper analyzes bank customers' perception in relation to the service quality factors explaining customer satisfaction. This study has applied descriptive and regression research design using SERVQUAL approach to analyze service quality factors affecting customer satisfaction. A survey was conducted to collect data from bank customers using structural questionnaire in Kathmandu valley in 2017. All together 250 questionnaires were distributed to the bank customers and only 175 were received in usable form which represents response rate of 70 percent. Result of the study indicates that bank service quality factors affect customer satisfaction. Finally, this paper concludes that bank service quality factors reliability, assurance, tangible, empathy and responsiveness determine the level of customer satisfaction. Tangible, assurance and empathy are strong and have more explaining power of customer satisfaction in Nepalese commercial banks.
\end{abstract}

Key words: Service quality, reliability, responsiveness, assurance, empathy, tangible and customer satisfaction.

\section{Introduction}

In the modern competitive and globalized business age, accomplishing the higher level customer satisfaction is challenging task in service sector. Satisfaction plays a vital role in attracting customers (Patterson \& Spreng, 1997). Customer satisfaction is crucial element of customer to purchase product and only satisfied customers are ready to share their positive thoughts with others (Mittal \& Kamakura, 2001).The use of the knowledge of customer satisfaction is vital to establish and maintain a long-term relationship with customers and preserving competitiveness (Kumar \&Reinartz, 2006). The customer satisfaction helps to measure whether product and services supplied by a firm meet or exceed the expectation of customers or not. It is an indicator to show whether customers will make repurchase decision or not along with loyalty (Boonlertvanich, 2011).Considering the significance of customer satisfaction, banks need to analyze and maintain sound and stable relationship with customers for their satisfaction.

Parasuraman, Zeithaml, and Berry (1988) analyzed five service quality dimension factors tangibility, reliability, responsiveness, assurance, and empathy in banking sector to determine

* Lecturer, Shanker Dev Campus, Tribhuvan University, Nepal 
the customer satisfaction. The responsiveness of the service quality dimension is crucial factors for customer satisfaction and loyalty (Johnston, 1997). Customer satisfaction act as mediator which bridge between service qualities and customer loyalty (Caruana, 2002). There is positive association among service quality, customer satisfaction and loyalty in banking sector (Veloutsou, Daskou, \& Daskou, 2004).Researchers have revealed that customer satisfaction has measurable impact on firm's financial performance (Chalmeta, 2006), on customer retention (Voss \& Voss, 2008), on purchase intention (Carter, 2010) and on level of competition, offering of incentives, product innovation, increase in use of technology (Mohammad, 2015).

In the modern business environment, wants, needs and expectations of customers are quickly and rapidly changed. Banks cannot provide superior service to the customers in the absence of knowledge of customers' expectations. The customer expectation can be identified through the knowledge of level of satisfaction of customers (Jham \& Khan, 2009).Different factors influence the level of customers' satisfaction. The factors affecting customer should be identified and analyzed for customer satisfaction.

The economic activities and growth of any country is affected with the development of financial institutions and markets. The most of Nepalese economic activities are influenced with expansion and growth of banking system. In Nepal, retail banking as service sector is rendering various services to the customers. Rapid expansion, reforms and growth of banking system of Nepal have been made in the past three decades with the government policy of liberalization and privatization. The unfair competition, changes in technology, instability of government, changes of policies, rules and regulations, more demanding of customers, environmental changes are the fear of economic uncertainties and challenges of Nepalese banking sector. In this situation, Nepalese banks have to formulate sound plans, policies and strategies and should provide more quality services to the customers to make them more loyal with the determination of influencing factors of customer satisfaction.

The prior studies on service quality and customer satisfaction and their issues were based on developed countries. Minimal similar research studies have been done on developing countries, and these studies are mainly focused on determinants of service quality and customer satisfaction. Due to dynamic and globalized environmental factors, Nepalese firms are facing tremendous challenges for their survival, expansion and growth which affect in their performance. The preponderance of prior theoretical and empirical studies on service quality on customer satisfaction carried out in developed and developing countries but a very limited studies have been administered in developing countries and there is lacking in-depth studies in under-developing countries like Nepal. Thus, this paper is an attempt to analyze service quality factors of customer satisfaction and examine the effect of service quality determinants on customer satisfaction in Nepalese commercial banks.

\section{Objective of the Study}

The major objective of this study is to analyze service quality factors and examine their impact on customer satisfaction of Nepalese commercial banks. The specific objectives of this paper are as follows: 
a. To analyze the service quality factors of customer satisfaction in Nepalese commercial banks.

b. To examine the impact of service quality factors on customer satisfaction in Nepalese commercial banks.

The remaining part of the paper has been divided into four sections. Section two is for brief literature review of service quality on customer satisfaction. Section three deals with research methodology. Section four covers analysis and findings of the study. Finally, section five concludes the results of this paper.

\section{Literature Review}

Customer loyalty plays a vital role in the success of any service sector because loyal customers are true assets of any organization. It is believed that improvement in service quality will boost customer loyalty. Parasuraman et al. (1988) applied a multiple items scale analysis for measuring consumer perception of service quality and revealed that banking sector is considering customer satisfaction as one of the factor for smooth functioning of organization. Banks are implementing new and advanced tool and technique to satisfy their customers. The finding of study has concluded that five service quality dimensions are major factors to make more customer satisfaction in banking sector which are tangibles, reliability, responsiveness, assurance and empathy.

Andreassen(1994) analyzed satisfaction, loyalty and reputation as indicators of customer orientation in public sector through survey from 100 business executives of local government service and argued that customer loyalty is originated through reputation and image of service sector. The corporate image and financial performance are linked with each other. Heskett, Jones, Loveman, Sasser and Schlesinger (1994) developed a popular model 'Service Profit Chain' and examined the relationships among customer satisfaction, loyalty, profit and growth, worth of goods and delivered services to customer and organization employee ability, pleasure, loyalty and productivity. Result of the study confirmed that service quality has make customer satisfaction and increase loyalty.

In the study of satisfaction, repurchase intent and repurchase behavior for investing moderating effect of customer characteristics, Mittal and Kamakura (2001) applied conceptual model for satisfaction rating and repurchase behavior to a large scale study of 100,040 customers and revealed that customer satisfaction is a crucial element of customer wishes for upcoming purchases. The customers who are satisfied are ready to share their positive thoughts with others.

Ravichandran, Mani, Kumar, and Prabhakaran (2010) applied descriptive research design using SERVQUAL scale model to analyze influences of service quality on customer satisfaction from 300 bank customers and found that customer satisfaction has a great importance in the 
service sectors especially in banking field because customer satisfaction is directly linked with loyalty and goodwill of the organization.

Customer satisfaction helps in measuring whether products and services supplied by company meet or further exceed the expectations of customers. Customer satisfaction is an indicator which shows whether the customers will make repurchase decision or not along with their loyalty (Boonlertvanich,2011). The study has concluded that feeling of happiness which is gained by achieving customers' goals can be considered to increase customer satisfaction.

Wilson, Zeithaml, Bitner, and Gremler(2012) established a theoretical model in which service quality, customer satisfaction and loyalty are correlated in one structure. As stated in the model, service quality dimensions such as reliability, responsiveness, assurance, empathy and tangibility create service quality. Situational and personal factors as well as price and product factor have impact on customer satisfaction. Badara, Mat, Mujtaba, Al-Refai, Badara, and Abubakar (2013) observed that measuring satisfaction help to identify the status of the organization regarding customer satisfaction. In this competitive world, customer needs have to be addressed properly by different service sectors and many service providers are shifting their focus from product to customer.

Lau, Cheung, Lam and Chu (2013) used SERVQUAL model to analyze service quality dimensions (reliability, assurance, tangibility, empathy and responsiveness) in banking service environment and observed that responsiveness focuses on helping customer and provide accurate services. Many banks try to customize their services depending upon the level of customer, as well as they try to personalize their services, which helps to enhance customer satisfaction. Similarly, customer wants assurance from bank. Thus, bank staff must explain each and every product and services to customer in detail, so that customer will feel comfortable with banking services. Finally, result of the study has concluded that bank employee should treat each and every customer individually to assure empathy because each and every customer are unique.

\section{Research Methodology}

\section{Research Design}

This paper has employed descriptive and regression research design to analyze various service quality factors influencing on consumer satisfaction. The descriptive and regression research design under SERVQUAL model are used to analyze the perception of bank customers about service quality factors affecting customer satisfaction of banking sector in Nepal.

\section{Nature and Source of Data}

This study is based on primary data sources. The data is collected to understand and analyze the view of bank customers about service quality factors and customer satisfaction. For this purpose, questionnaire survey was administered to collect the views of customers about service quality related factors from Nepalese commercial banks. A set of questionnaires were 
prepared to survey the responses of bank customers. Set of 250 questionnaires containing total of eleven questions were distributed to the bank customers. There were five questions about the respondent's profile. Five questions were designed in a five point Likert scale types to identify the degree of agreement or disagreement containing four statements of each of reliability, assurance, tangible, empathy and responsiveness in relation to service quality factors affecting customer satisfaction. At the end, one open-end question was included to obtain the written comment of respondents regarding the bank service quality factors influencing customer satisfaction in Nepal.

\section{Population and Sample}

In this paper, all the individual bank customers who have their account with different banks operating as commercial banks licensed by Nepal Rastra Bank till mid-July 2017 are considered as population. This study includes only those customers who have bank account in commercial banks within Kathmandu valley. In this paper, only 175 bank customers of commercial banks were selected as sample for data collection using convenience sample technique. This study was administered during the period of August, September and October, 2017.

\section{Analytical Tools}

In this paper, collected data are processed and analyzed based on software SPSS (version 20), and MS-Excel. In this study, descriptive analysis, regression analysis along with t-test, F-test, and Adjusted $\mathrm{R}^{2}$ are used to analyze data and examine the impact of service quality factors on customer satisfaction in banking sector.

\section{Variables}

In this paper, the level of customer satisfaction (CSAT) is considered as independent variable. The prior theoretical and empirical studies have observed several service quality related factors affect customer satisfaction. In this study, reliability (REL), assurance (ASS), tangible (TAN), empathy (EMP) and responsiveness (RES) of commercial banks towards customers are considered as explanatory (independent) variables. Thus, explanatory variables used in this paper are RATER.

\section{Model Specification}

The multiple regression equation under SERVQUAL model are used to examine the impact of explanatory (service quality) variables on customer satisfaction. The regression model of equation (1) is used to examine the effect of explanatory variables on customer satisfaction in banking sector of Nepal.

Customer satisfaction $(C S A T)=a_{0}+\beta_{1} R E L+\beta_{2} A S S+\beta_{3} T A N+\beta_{4} E M P+\beta_{5} R E S+\varepsilon_{t}$

$a_{0}$ is coefficient of constant, $\beta_{1}, \beta_{2}, \beta_{3}, \beta_{4} \& \beta_{5}$ indicate coefficient of explanatory variables and $\varepsilon_{\mathrm{t}}$ refers error term. 


\section{Results and Discussion}

This section of paper attempts to analyze survey data related with service quality and customer satisfaction collected from bank customers. The opinions, perceptions, and characteristics of bank customers with respect to the service quality factors affecting customer satisfaction in Nepalese context are presented and analyzed in the following three sub-sections.

\section{Profile of the Respondents}

In this study, respondents are customers of commercial banks in Kathmandu valley. Table 1 shows the disaggregated characters of respondents based on gender, age group, academic qualification, occupation, and income of the bank customers.

Table 1: Profile of Respondents Based on Personal Characteristics

\begin{tabular}{|c|c|c|}
\hline Investors' Character & Number & Percentage \\
\hline \multicolumn{3}{|l|}{ Gender: } \\
\hline Male & 133 & 76.00 \\
\hline Female & 42 & 24.00 \\
\hline Total & 175 & 100.00 \\
\hline \multicolumn{3}{|l|}{ Age Group (in years): } \\
\hline 20 and below & 05 & 02.86 \\
\hline $21-30$ & 32 & 18.29 \\
\hline $31-40$ & 45 & 25.71 \\
\hline $41-50$ & 82 & 46.86 \\
\hline Above 50 & 11 & 06.28 \\
\hline Total & 175 & 100.00 \\
\hline \multicolumn{3}{|l|}{ Academic Qualification: } \\
\hline PCL or XII and below & 34 & 19.43 \\
\hline Bachelor & 90 & 51.43 \\
\hline Master & 39 & 22.29 \\
\hline MPhil and above & 12 & 06.85 \\
\hline Total & 175 & 100.00 \\
\hline \multicolumn{3}{|l|}{ Occupation } \\
\hline Service & 36 & 20.57 \\
\hline Business & 42 & 24.00 \\
\hline Self-employed & 28 & 16.00 \\
\hline Others & 69 & 39.43 \\
\hline Total & 175 & 100.00 \\
\hline \multicolumn{3}{|l|}{ Income per month (in Rs): } \\
\hline Upto 20,000 & 61 & 34.86 \\
\hline $20,001-40,000$ & 88 & 50.29 \\
\hline $40,001-60,000$ & 21 & 12.00 \\
\hline More than 60,000 & 05 & 2.85 \\
\hline Total & 175 & 100.00 \\
\hline
\end{tabular}


Table 1 shows that out of the total respondents from bank customers, majority (76\% percent) of the customers of Nepalese commercial banks are male. Similarly, age group of bank customers has been classified into five categories. 46.86 percent customers are 41 to 50 years, 2.86 percent are 20 years or below and 6.28 percent are above 50 years of age. The survey result shows that the most of bank customers are in age group of 31 to 50 years of age. The academic qualification of the respondents indicates that 51.43 percent bank customers have qualification of bachelor degree which specifies the most of bank customers have qualification of bachelors. Occupation of bank customers are 20.57 in service, 24 percent in business, 16 percent in self-employed and remaining 39.43 percent are in other sectors. Finally, Table 1 shows the level of income of the respondents and indicates that bank customers have monthly income of Rs 20,001 toRs 40,000.

\section{Descriptive Statistics of Service Quality and Customer Satisfaction}

The paper has applied descriptive statistics to describe service quality factors affecting customer satisfaction. Table 2 presents summary of descriptive statistics of customer satisfaction and its explanatory variables.

Table 2: Descriptive Statistics of Variables

\begin{tabular}{ccccccc}
\hline S. N. & Variables & $\mathrm{N}$ & $\begin{array}{c}\text { Minimum } \\
\text { mean score }\end{array}$ & $\begin{array}{c}\text { Maximum } \\
\text { mean score }\end{array}$ & $\begin{array}{c}\text { Composite } \\
\text { mean score }\end{array}$ & $\begin{array}{c}\text { Standard } \\
\text { Deviation }(\%)\end{array}$ \\
\hline 1 & CSAT & 175 & 2.77 & 3.49 & 3.02 & 23.67 \\
2 & REL & 175 & 2.63 & 3.31 & 3.08 & 19.71 \\
3 & ASS & 175 & 3.18 & 4.14 & 3.81 & 32.84 \\
4 & TAN & 175 & 3.41 & 4.45 & 4.11 & 35.69 \\
5 & EMP & 175 & 3.07 & 4.16 & 3.78 & 41.25 \\
6 & RES & 175 & 2.96 & 3.68 & 3.54 & 24.36 \\
\hline
\end{tabular}

Source: Author's own calculation based on survey data 2017.

Table 2 shows the result of descriptive statistics of all variables. The CSAT, REL, ASS, TAN, EMP, and RES all have positive composite mean values (score). The highest score of level of customer satisfaction (CSAT) is 3.49, least is 2.77 and average of composite is 3.02. The result indicates that level of satisfaction of bank customers is above average. The composite mean values of REL, ASS, TAN, EMP and RES are 3.08,3.81, 4.11, 3.78 and 3.54 respectively. The composite mean values of all explanatory variables with higher than 3 show bank customers agree that all service quality factors (REL, ASS, TAN, EMP and RES) of banks affect the level of customer satisfaction. Bank customers have given the highest importance on tangible, second importance on assurance and so on and least importance on reliability. Further, Table 2 presents the minimum and maximum mean score/values of each variables. Finally, descriptive result shows standard deviation of each variable which indicates the variation of customers' priority on each factors affecting customer satisfaction. 
Regression Analysis on Service Quality and Customer Satisfaction

In this paper, regression models have been used to analyze relationship between explanatory variables and customer satisfaction. Table 3 presents regression results of multivariate regression models under previous specified equations to examine the impact of various service quality factors on customer satisfaction in Nepalese commercial banks.

Table 3: Regression Relationship of Customer Satisfaction with Explanatory Variables

Model: $C S A T=a_{0}+\beta_{1} R E L+\beta_{2} A S S+\beta_{3} T A N+\beta_{4} E M P+\beta_{5} R E S+\varepsilon_{\mathrm{t}}$

\begin{tabular}{ccccccccc}
\hline Variables & Constant & REL & ASS & TAN & EMP & RES & Adj. R2 & F \\
\hline CSAT & 4.931 & 0.890 & 1.945 & 0.814 & 1.475 & 0.728 & 0.674 & $26.309^{* *}$ \\
T & $\left(9.602^{* *}\right)$ & $\left(3.917^{*}\right)$ & $\left(5.014^{* *}\right)$ & $\left(4.537^{* *}\right)$ & $\left(5.120^{* *}\right)$ & $\left(4.296^{* *}\right)$ & & \\
SE & $(0,514)$ & $(0227)$ & $(0.388)$ & $(0.179)$ & $(0.288)$ & $(0.169)$ & & \\
\hline
\end{tabular}

Source: Author's own calculation based on survey data 2017.

Note: The figures in the parentheses are t-value and standard error, and asterisk sign indicates that result is significant level.' ${ }^{\prime \prime}$ Indicates statistical significance at 5 percent level and '**' indicates statistical significance at 1 percent level (two tailed). Also reported are the F-statistics and Adjusted $R^{2}$.

Table 3 presents regression result of multiple regression models to measure the combined effect of explanatory variables on customer satisfaction. The regression coefficients show positive relationship of REL, ASS, TAN, EMP and RES with CSAT. The regression result indicates that ASS, TAN, EMP and RES have positive impact on CSAT and are statistically significant at 1 percent level whereas REL has positive impact but is significant only at 5 percent level. The regression coefficient of REL specifies that one point increase in reliability leads to 0.89 unit on level of customer satisfaction, one point increase in assurance leads to 1.945 point level of customer satisfaction and so on. The coefficient of determinants of multiple regression models shows the predicting and explaining power of explanatory variables. The coefficient of determinants (Adj. $R^{2}$ ) of the model is 0.614 which shows predicting power of multiple regression models is 61.4 percent to explain level of customer satisfaction by its explanatory variables. The F-statistics of the models is statistically significant at 1 percent level which indicates that all the regression models used in this paper are statistically significant. This result implies that regression models used in estimation of level of customer satisfaction with its explanatory variables are fitness of test of the overall models.

\section{Conclusion}

Satisfaction plays vital role in attracting customers to make ready to share their positive thoughts to purchase products. The customer satisfaction is the key to long-term success of any organization and it helps to measure whether product and services supplied by a firm meet the expectation of customers or not. The success of business activities and economic 
growth depends on customer satisfaction. Service quality dimension factors tangibility, reliability, responsiveness, assurance, and empathy measure the level of customer satisfaction in banking sector.

This paper has been attempted to analyze service quality related factors influencing customer satisfaction of Nepalese banks using descriptive and regression research design. This paper is based on primary data sources. Data was collected through questionnaire survey from bank customers using convenience sample technique to understand and analyze their views about service quality factors and customer satisfaction.

The survey result of the paper reveals positive association of service quality factors with customer satisfaction. Nepalese bank customers agree that reliability, assurance, tangible, empathy, and responsiveness are the determinants of customer satisfaction in banking sector. Finally, regression result of this study concludes that all service quality factors reliability, assurance, tangible, empathy, and responsiveness have significant impact on customer satisfaction. These service quality factors have strong explaining power of the level of customer satisfaction in Nepalese commercial banks.

\section{References}

Andreassen, T. W. (1994). Satisfaction, loyalty, and reputation as indicators of customer orientation in the public sector. International Journal of Public Sector Management, 7(2), 16-34.

Badara, M. A. S., Mat, N. K. N., Mujtaba, A. M., Al-Refai, A. N., Badara, A. M., \& Abubakar, F.M. (2013). Direct effect of service quality dimensions on customer satisfaction and customer loyalty in Nigerian Islamic bank. Journal of Management, 3(1), 6-11.

Boonlertvanich, K. (2011). Effect of customer perceived value on satisfaction and customer loyalty in banking service: The moderating effect of main bank status. International Journal of Business Research, 11(6),40-54.

Caruana, A. (2002). Service loyalty: The effects of service quality and the mediating role of customer satisfaction. European journal of marketing, 36(7/8), 811-828.

Carter, T. J. (2010). The challenges of managers keeping customers. International Management Review, 6(2), 20-27.

Chalmeta, R. (2006). Methodology for customer relationship management. The journal of Systems and Software, 79(2006), 1015-1024.

Heskett, J. C., Jones, T. O., Loveman, G. W., Sasser, W. E., \& Schlesinger, L. A. (1994). Putting the service-profit chain to work. Harvard Business Review, 72(2), 164-174.

Jham, V., \& Khan, K. M. (2009). Customer satisfaction and its impact on performance in banks: A proposed model. South Asian Journal of Management, 16(2), 109-126.

Johnston, R. (1997). Identifying the critical determinants of service quality in retail banking: Importance and effect. International Journal of bank marketing, 15(4), 111-116. 
Khanal, K. (2015). Measuring customer satisfaction of commercial banks in Nepal. Management Dynamics (A Journal on Management and Economics),18(1), 28-34.

Kumar, V., \& Renartz, W. J. (2006). Customer relationship management: A data based approach. Hoboken: Wiley \& Sons.

Lau, M. M., Cheung, R., Lam, A. Y., \& Chu, Y. T. (2013). Measuring service quality in the banking industry: A Hong Kong based study. Contemporary Management Research, 9(3), 263.

Mittal, V., \& Kamakura, W. A. (2001). Satisfaction, repurchase intent, and repurchase behavior: Investigating the moderating effect of customer characteristics. Journal of marketing Research, 38(1), 131-142.

Mohammad, H. I. (2015). 7 Ps marketing mix and retail bank customer satisfaction in financial service sector. Journal of Managing Service Quality, 17(3), 259-274.

Parasuraman, A., Zeithaml, V.A., \& Berry, L. L. (1988). SERVQUAL: A Multiple-Item Scale for Measuring Consumer Perceptions of Service Quality. Journal of Retailing, 64(1),12-40.

Ravichandran, K., Prabakaran, S., \& Kumar, S. A. (2010). Application of SERVQUAL model on measuring service quality: A Bayesian approach. Enterprise Risk Management, 1(1), 145-169.

Patterson, P. G., \& Spreng, R. A. (1997). Modelling the relationship between perceived value, satisfaction and repurchase intentions in a business-to-business, services context: an empirical examination. International Journal of service Industry management, 8(5), 414- 434.

Veloutsou, C., Daskou, S., \& Daskou, A. (2004). Are the determinants of bank loyalty brand specific? Journal of Financial Services Marketing, 9(2), 113-125.

Voss, G. B., \& Voss, Z. G. (2008). Competitive density and the customer acquisition retention trade-off. Journal of Marketing, 72(6), 3-18.

Wilson, A., Zeithaml, V. A., Bitner, M. J., \& Gremler, D. D. (2012). Services marketing: Integrating customer focus across the firm. New York: McGraw Hill. 